\title{
Is there any Relation of Dimple on the Chin with Urine Nitrates?
}

\author{
Muhammad Imran Qadir, Noor Arif* \\ Institute of Molecular Biology and Biotechnology, Bahauddin Zakariya University, Multan, Pakistan \\ *Corresponding Author: Noor Arif, Institute of Molecular Biology and Biotechnology, Bahauddin \\ Zakariya University, Multan, Pakistan
}

\begin{abstract}
Urine contains different types of chemicals called as nitrates. The entrance of bacteria in the urinary tract cause the conversion of urine nitrates into nitrites. The bacteria which cause the infection of urinary tract are E. coli and some gram-negative bacteria. Cleft chin or dimple on the chin can be inherited from the parents or grandparents. This is the $Y$ shaped cleft on the chin that is caused by the genetics in humans. Muscle of the mentalis fails to fuse and it leaves a gap. The main objective of this study is to correlate the urine nitrates with dimple on the chin. A total of 100 subjects participated in the research. All the subjects were undergraduate students in Bahauddin Zakariya University, Multan, Pakistan. The relation of nitrates in urine with chin dimple was observed. Urine test was done to check the nitrates level. It was inferred from the study that people with absence of chin dimple has high ratio of absence of urine nitrates in them. So there is no relation of urine nitrates with the dimple on the chin.
\end{abstract}

Keywords: Urine nitrates, Chin dimple, Urinalysis, Urinary tract.

\section{INTRODUCTION}

Urine contains different types of chemicals called as nitrates. The entrance of bacteria in the urinary tract causes the conversion of urine nitrates into nitrites. The bacteria which cause the infection of urinary tract are E. coli and some gram-negative bacteria. These bacteria release an enzyme called as urease that acidify our urine. These bacteria infect the kidneys, bladders and ureters in the body and they release an enzyme that leads to the conversion of nitrates. The presence of these nitrites is the symptom of infection in urinary tract. This infection mostly occurs in women due to their short length of the urethra. This leads to the inflammation of these parts as urethra, kidneys. The presence of nitrates can be checked by the urinalysis. The symptoms include the burning, change in color or foul smell of the urine. If this infection of urinary tract is not properly treated, then it will lead to serious complications in the body. Theses complications might include fever, chill, low back pain or side pain. A patient with infection of urinary tract is prescribed with antibiotics to treat this infection. Some actions often cause decrease in the urinary tract infection. By drinking adequate amount of water on daily basis can flush out the bacteria out of the urinary tract. Pure cranberry juice is also used for the treatment of infection. Apple cider vinegar mixed with water helps to treat infection.

Cleft chin or dimple on the chin can be inherited from the parents or grandparents. This is the $\mathrm{Y}$ shaped cleft on the chin that is caused by the genetics in humans. Muscle of the mentalis fails to fuse and it leaves a gap. All the cleft chin and dimple on the chin are not same, cleft is more prominent than the dimple on the chin. Cleft is a deep fissure on the chin while the dimple is a slight hollow portion in the chin. People who have this are the attention seekers and they are powerful and entertaining.

The main objective of this study is to correlate the urine nitrates with dimple on the chin.

\section{Materials AND Methods}

\subsection{Measurement of Urine Nitrates}

Urine test was done to check the presence of urine nitrates. Urine sample was taken in the collection container and it was filled up to the mark. The strips were dipped in the sample for 2 to 3 seconds and 
then after the appearance of colors, the strip was matched with suggestion chart present on the container. Note down the results.

\subsection{Task Design}

A total of 100 subjects participated in the research. All the subjects were undergraduate students in Bahauddin Zakariya University, Multan, Pakistan. The relation of nitrates in urine with chin dimple was observed. Urine test was done to check the nitrates level.

\subsection{Statistical Analysis}

Statistical analysis was performed by using MS Excel.

\section{ReSUlts}

Table 1 and 2 showed the relation of chin dimple with urine nitrates. In Table 1, normal value of nitrates was more in people with absence of chin dimple in them. In Table 2, male and female with absence of chin dimple had positive value of urine nitrates present in them.

Table1. Relation of urine nitrates with dimple on the chin

\begin{tabular}{|c|c|c|}
\hline Chin Dimple & Positive Urine Nitrates & Negative Urine Nitrates \\
\hline Presence & $\mathbf{0 \%}$ & $\mathbf{1 7 \%}$ \\
\hline Absence & $\mathbf{4 \%}$ & $\mathbf{7 9 \%}$ \\
\hline
\end{tabular}

Table2. Relation of positive value of urine nitrates with dimple on the chin

\begin{tabular}{|c|c|c|}
\hline Chin dimple & Presence of chin dimple & Absence of chin dimple \\
\hline Male & $0 \%$ & $100 \%$ \\
\hline Female & $0 \%$ & $100 \%$ \\
\hline
\end{tabular}

\section{DISCUSSION}

Radomski, Palmiri and Lee Hearn did a study on the concentration of nitrates in humans. Urine nitrates were analyzed and they observed that nitrate level in drinking water is the reason of concentration of nitrates in urine.

Robert Cox and Frank did a study on determination of nitrate and nitrite in blood and urine. Methodology was developed to check their presence. Reduction to nitric oxide takes place and differentiation between them is done by selection of agents for reduction and different conditions.

\section{CONCLUSION}

It was inferred from the study that people with absence of chin dimple has high ratio of absence of urine nitrates in them. So there is no relation of urine nitrates with the dimple on the chin.

\section{REFERENCES}

[1] Boo-Chai K. The facial dimple-Clinical study and operative technique. Plastic and Reconstructive Surgery. 1962 Aug 1; 30(2):281-8.

[2] Daponte AP, Vienna A, Brant L, Hauser G. Cheek dimples in Greek children and adolescents. International Journal of Anthropology. 2004 Oct 1; 19(4):289-95.

[3] Qadir MI, Javid A (2018) Awareness about Crohn's Disease in biotechnology students. Glo Adv Res J Med Medical Sci, 7(3): 062-064.

[4] Qadir MI, Saleem A (2018) Awareness about ischemic heart disease in university biotechnology students. Glo Adv Res J Med Medical Sci, 7(3): 059-061.

[5] Qadir MI, Ishfaq S (2018) Awareness about hypertension in biology students. Int J Mod Pharma Res, 7(2): 08-10.

[6] Qadir MI, Mehwish (2018) Awareness about psoriasis disease. Int J Mod Pharma Res, 7(2): 17-18.

[7] Qadir MI, Shahzad R (2018) Awareness about obesity in postgraduate students of biotechnology. Int J Mod Pharma Res, 7(2): 14-16.

[8] Qadir MI, Rizvi M (2018) Awareness about thalassemia in post graduate students. MOJ Lymphology \& Phlebology, 2(1): 14-16.

[9] Qadir MI, Ghalia BA (2018) Awareness survey about colorectal cancer in students of M. Phil Biotechnology at Bahauddin Zakariya University, Multan, Pakistan. Nov Appro in Can Study, 1(3): NACS.000514.2018 
[10] Qadir MI, Saba G (2018) Awareness about intestinal cancer in university student. Nov Appro in Can Study, 1(3): NACS.000515.2018.

[11] Radomski JL, Palmiri C, Hearn WL. Concentrations of nitrate in normal human urine and the effect of nitrate ingestion. Toxicology and applied pharmacology. $1978 \mathrm{Jul}$ 1;45(1):63-8.

[12] Cox RD, Frank CW. Determination of nitrate and nitrite in blood and urine by chemiluminescence. Journal of analytical toxicology. 1982 May 1;6(3):148-52.

Citation: Muhammad Imran Qadir, Noor Arif, "Is there any Relation of Dimple on the Chin with Urine Nitrates?" International Journal of Research Studies In Biosciences (Ijrsb), Vol. 7, no. 6, pp. 17-19, 2019. http://Dx.Doi.org/10.20431/2349-0365.0706004

Copyright: (C) 2019 Authors. This is an open-access article distributed under the terms of the Creative Commons Attribution License, which permits unrestricted use, distribution, and reproduction in any medium, provided the original author and source are credited. 